Available online on 15.02.2020 at http://jddtonline.info
Open Access to Pharmaceutical and Medical Research
unrestricted non-commercial use, provided the original work is properly cited

open Access

Research Article

\title{
Dissolution Method Development and Validation for Estimation of Noscapine Tablets
}

\author{
Jigar Vyas *, Jaydip Solanaki, Kapil Daxini, Puja Vyas, Neha Pal \\ Department of Quality Assurance, Sigma Institute of Pharmacy, Bakrol- Vadodara- 390019 Gujarat India
}

\begin{abstract}
A dissolution method was developed and UV spectrophotometry was developed for the evaluation of the dissolution of tablets containing 15 mg Noscapine .The dissolution medium $0.1 \mathrm{~N} \mathrm{HCl}$ was found suitable to ensure sink conditions. USP Apparatus $2,900 \mathrm{~mL}$ dissolution medium 45 minutes and 100 RPM were fixed. Dissolution profiles were generated at 10,15, 20, $30 ; 45$ min. Dissolution samples were analyzed with UV spectrophotometer at $213 \mathrm{~nm}$. The UV method for determination of tablet was developed and validate $\mathrm{d}$. The method presented linearity $\left(\mathrm{R}^{2}=\right.$ 0.999 ) in the concentration range of $1-9 \mu \mathrm{g} / \mathrm{mL}$. The recoveries were good, ranging from $97.18 \%$ to $101.45 \%$. The intraday and Interday precision results were $0.54 \%$ and $0.78 \%$ RSD, respectively. The developed dissolution test is adequate for its purpose and can be applied for the quality control of tablets.
\end{abstract}

Keywords: Dissolution test; Noscapine; Tablets; UV Spectrophotometry method

Article Info: Received 24 Nov 2019; Review Completed 18 Jan 2020; $\quad$ Accepted 29 Jan 2020; Available online 15 Feb 2020

Cite this article as:

Vyas J, Solanaki J, Daxini K, Vyas P, Pal N, Dissolution Method Development and Validation for Estimation of Noscapine

Tablets, Journal of Drug Delivery and Therapeutics. 2020; 10(1-s):159-164 http://dx.doi.org/10.22270/jddt.v10i1-s.3891

*Address for Correspondence:

Dr Jigar R. Vyas Professor, Sigma institute of Pharmacy, Ajwa-Nimeta road, vadodara-390019 Gujarat, India,

\section{INTRODUCTION}

Dissolution is defined as the rate and extent in which the amount of drug substance dissolved over a period of time. It is expressed as percentage release of drug substances present dosage forms like Tablets, Capsules, ointments and oral suspensions.[1] In the present study dissolution method was developed for immediate release tablet(15 mg Noscapine).

The dissolution method developed for tablets is to evaluate the release pattern. [2]

In vitro dissolution tests for immediate release solid oral dosage forms are used: (a) to assess the lot-to-lot quality of a drug product;

(b) To assess the stability of the drug product;

(c) To ensure continuing product quality and performance after certain changes, such as changes in the formulation, the manufacturing process, the site of manufacture, and the scale-up of the manufacturing process; and

(d) To develop new formulations. In formulation development, dissolution testing can aid in the selection of excipients, help optimize the manufacturing process, and enable formulation of the test product to match the release of the reference product [3]
For immediate release products the basket (apparatus 1, usually at $100 \mathrm{rpm}$ ) and paddle (Apparatus 2, usually at 50 to $75 \mathrm{rpm}$ ) are conventional. Immediate release means $75 \%$ of the API is dissolved within 45 minutes, while the term rapidly dissolving means $85 \%$ API dissolved in 30 minutes and very rapidly dissolving 85\% API in dissolved 15 minutes are important in dissolution testing.

Different Medias should be considered for immediate release products during development studies which are following:

- $\quad$ PH 1.2 buffer or 0.1 M Hydrochloric acid.

- $\mathrm{pH} 4.5$ buffer

- $\quad$ pH 6.8 buffer

- Water may be considered as an additional medium

For development purposes the generation of dissolution patterns at short intervals such as 10, 15, 20, 30 and 45 minutes in the above media are recommended. [2]

The validation of the dissolution test can be divided into two parts.

- Equipment validation; equipment has to be calibrated taking into consideration the specifications for geometry and alignment of the dissolution apparatus. 
- Test validation and requires the study of the performance parameters like accuracy, precision, robustness

It is true that a more discriminating dissolution method is preferred, but it is also true that a reliable dissolution test is of utmost importance.

A dissolution test with good precision makes it possible to efficiently compare several alternative formulation candidates to select the dosage form with the most suitable and reproducible drug release profile. [4]

Following are the parameters that are usually considered during method development for Dissolution.

\section{- $\quad$ Selection of dissolution medium}

Selection of dissolution medium depends upon following parameters.

a. Type of formulation (Immediate release or modified release).

b. Solubility characteristics of active component.

c. Type formulation design, (Tablets, Oily suspension, Soft gel capsule, hard gel capsule, etc.)

\section{- $\quad$ Selection of RPM}

Apparatus, Type of formulation and solubility characteristics of active substances are parameters which are used for selection of RPM

Any change in apparatus and use of higher RPM other than recommended parameters should be justified.

\section{- $\quad$ Selection of dissolution time interval}

Dissolution time is defined as the time in minutes at which maximum amount ( $+80 \%$ of label claim) of drug is dissolved. For immediate release dosage forms, $30 \mathrm{~min}$. to $60 \mathrm{~min}$. is recommended as dissolution time.

In some cases dissolution time may be higher i. e. up to $90 \mathrm{~min}$ to $120 \mathrm{~min}$.

In such cases suitable justification should be provided. For modified release formulations (delayed release, enteric coated and sustained release), time depends upon design of formulation, site of action and therapeutic use.

Time for such formulations may be from about 6 hrs to 24 hrs or may be higher.

\section{- Selection of other parameters}

Media volume:

The volume of dissolution media is ideally $900 \mathrm{ml}$, however if label claim is less than $5 \mathrm{mg}$ and if active substances has less absorbance at selected wavelength, then in that case dissolution volume can be reduced to $500 \mathrm{ml}$.

Media temperature:

The dissolution media temperature is fixed (i. e. $37.0^{\circ} \mathrm{C}$ ) [4]

\section{Introduction to drug}

Noscapine is (3S)-6,7-Dimethoxy-3-[(5R)-4-methoxy-6methyl-5,6,7,8-tetrahydro[1,3]dioxolo[4,5-g]isoquinolin-5yl]isobenzofuran-1(3H)-one (Figure 1). It is practically insoluble in water but soluble in organic solvents like in acetic acid (100), Ethanol (95) and in diethyl ether. It is centrally acting Antitussive. [5-8] Noscapine inhibit bradykinin as the mode by which it functions. Noscapine's effect in treating strokes has been attributed to its
Bradykinin suppressive effect and its anti-cancer effect has been primarily attributed to its Microtubuleinterfering effect. [9]<smiles></smiles>

[MW=413.42 g/mol, chemical structure: C 22H23NO7]

\section{MATERIALS AND METHODS}

Noscapine reference standard (99.947\%) and noscapine tablets (containing $15 \mathrm{mg}$ Noscapine) were kindly given by Bharat Parenterals Pvt. Ltd, Haripura, and Savli.

Analytical reagent grade, Hydrochloric acid, anhydrous potassium hydrogen phosphate, sodium hydroxide were used. Freshly distilled water was used throughout the study. Phosphate buffer $\mathrm{pH}$ 6.8, Phosphate buffer $\mathrm{pH} 4.0,0.1 \mathrm{~N} \mathrm{HCl}$ was prepared according to USP 27.

\section{Apparatus}

The dissolution test was performed in a six-station Electrolab dissolution tester in accordance with USP 27 general methods. A Shimadzu UV-vis spectrophotometer (model UV-1800) using 1.0-cm quartz cells and UV probe software were used for all absorbance measurements. A digital $\mathrm{pH}$ meter was used to determine the $\mathrm{pH}$ of all solutions. The ultrasonic bath used for deaeration.

\section{Selection of Dissolution Media}

Solubility data were used as the basis for the selection of a dissolution medium for Noscapine.

\section{Quality Control Testing of 15-mg Noscapine Tablets}

Noscapine tablets containing $15 \mathrm{mg}$ of Noscapine were evaluated for color, shape, size, weight, variation, friability, disintegration time, hardness, drug content, and content uniformity.

\section{Optimization of Dissolution method}

The dissolution experiments were conducted in a six-station bath dissolution apparatus by adding Noscapine tablet $(n=6)$ in bowl of $900 \mathrm{~mL}$ of each dissolution medium, a paddle dissolution apparatus, and stirring speeds of 50,75 , and 100 RPM. The temperature was stabilized at $37 \pm 0.5^{\circ} \mathrm{C}$. Aliquots of $10 \mathrm{~mL}$ were withdrawn manually at $45 \mathrm{~min}$. The same volume of medium at $37 \pm 0.5^{\circ} \mathrm{C}$ was replaced for constant volume. The sample was filtered through Whatman No. 41 filter paper and analyzed spectrophotometrically at $213 \mathrm{~nm}$. The standard solution used in all dissolution tests was prepared using Noscapine equivalent to $15 \mathrm{mg}$. The UV spectrophotometric method was developed and validated.

\section{Validation of Dissolution Method}

The method was validated by the analysis of specificity, linearity and range, accuracy, precision (intermediate precision and repeatability) and robustness (change in analyst, laboratory, instrument). 


\section{Specificity}

A placebo sample of the reference formulation of tablets in the usual concentration of excipients was prepared to demonstrate reliability and reproducibility of the method. The placebo sample was transferred to vessels containing $900 \mathrm{~mL}$ of dissolution medium and stirred at $37{ }^{\circ} \mathrm{C}$ for 45 minute at 100 RPM using a paddle apparatus. Aliquots of the solutions were filtered through filter paper (Whatman No. 41) and analyzed by UV spectrophotometric method. [10]

Linearity: Aliquots of Noscapine stock solution $(100 \mu \mathrm{g} / \mathrm{mL})$ were diluted with $0.1 \mathrm{~N} \mathrm{HCl}$ to give concentrations of 1-9 $\mu \mathrm{g} / \mathrm{mL}(\mathrm{n}=5) .{ }^{[11-14]}$

\section{Accuracy:}

The recovery study was performed using Noscapine tablets. Noscapine reference substance was added to the dissolution vessels in known amounts at the $80 \%, 100 \%$, and $120 \%$ levels.12, 15, and $18 \mathrm{mg}$ of Noscapine reference standard respectively was added along with each 15-mg Noscapine tablet. The dissolution test was performed on Noscapine tablets for 45 min using $900 \mathrm{~mL}$ of $0.1 \mathrm{~N} \mathrm{HCl}$ as medium in a paddle apparatus at 100RPM. Aliquots of $10 \mathrm{~mL}$ were filtered through filter paper (Whatman No. 41) and analyzed by developed UV spectrophotometric method at the spiked concentration levels of $80 \%, 100 \%$, and $120 \%$, respectively. Each concentration was analyzed in triplicate. [11-14]

Table 1: Accuracy data for dissolution method

\begin{tabular}{|c|c|c|c|c|c|c|c|}
\hline $\begin{array}{c}\text { Tablet } \\
\text { amount }\end{array}$ & $\begin{array}{c}\text { Level of } \\
\text { addition (\%) }\end{array}$ & $\begin{array}{c}\text { Amount } \\
\text { added (mg) }\end{array}$ & Absorbance & $\begin{array}{c}\text { Total } \\
\text { amount }\end{array}$ & $\begin{array}{c}\text { Amount } \\
\text { recovered (mg) }\end{array}$ & $\begin{array}{c}\% \\
\text { Recovery }\end{array}$ & $\begin{array}{c}\text { Average \% } \\
\text { recovery }\end{array}$ \\
\hline- & 0 & - & 0.254 & 1.49 & - & - & - \\
\hline - & 0 & - & 0.257 & 1.51 & - & - & - \\
\hline- & 0 & - & 0.255 & 1.50 & - & - & - \\
\hline $15 \mathrm{mg}$ & & 12 & 0.423 & 2.69 & 11.89 & 99.09 & \multirow[t]{3}{*}{99.48779} \\
\hline $15 \mathrm{mg}$ & 80 & 12 & 0.427 & 2.72 & 12.17 & 101.45 & \\
\hline $15 \mathrm{mg}$ & & 12 & 0.421 & 2.68 & 11.75 & 97.91 & \\
\hline $15 \mathrm{mg}$ & & 15 & 0.467 & 3.01 & 15.01 & 100.07 & \multirow[t]{3}{*}{98.50276} \\
\hline $15 \mathrm{mg}$ & 100 & 15 & 0.463 & 2.97 & 14.73 & 98.18 & \\
\hline $15 \mathrm{mg}$ & & 15 & 0.461 & 2.96 & 14.58 & 97.24 & \\
\hline $15 \mathrm{mg}$ & & 18 & 0.507 & 3.29 & 17.85 & 99.15 & \multirow[t]{3}{*}{98.37142} \\
\hline $15 \mathrm{mg}$ & 120 & 18 & 0.506 & 3.28 & 17.78 & 98.76 & \\
\hline $15 \mathrm{mg}$ & & 18 & 0.502 & 3.25 & 17.49 & 97.18 & \\
\hline
\end{tabular}

\section{Precision}

Repeatability was determined by analyzing six samples of Noscapine tablets with the optimized dissolution test Aliquots were collected and evaluated by the UV method at $213 \mathrm{~nm}$. Thus, repeatability was evaluated with the relative standard deviation (RSD) of the data at the $100 \%$ level.

The evaluation of intermediate precision was performed using Noscapine tablets. The intermediate precision was determined on different time on same day (intraday) and different days (Interday) and the RSD values were calculated. The dissolution test was performed on six Noscapine tablets for $45 \mathrm{~min}$ using $900 \mathrm{~mL}$ of $0.1 \mathrm{~N} \mathrm{HCl}$ as dissolution medium in Apparatus 2 at 100 RPM. Aliquots of $10 \mathrm{~mL}$ were filtered with quantitative filter and analyzed by the UV spectrophotometric method. Each concentration was analyzed in triplicate. [11-14]

Table 2: Dissolution Release Rate of Noscapine Tablets in0.1 N HCl, Paddle Apparatus, 100 rpm

\begin{tabular}{|r|r|r|r|r|r|r|r|r|r|r|}
\hline $\begin{array}{c}\text { Sr } \\
\text { No. }\end{array}$ & $\begin{array}{c}10 \\
\text { minute }\end{array}$ & $\begin{array}{c}\text { \% drug } \\
\text { dissolved }\end{array}$ & $\begin{array}{c}15 \\
\text { minute }\end{array}$ & $\begin{array}{c}\text { \% drug } \\
\text { dissolved }\end{array}$ & $\begin{array}{c}\text { 20 } \\
\text { minute }\end{array}$ & $\begin{array}{c}\text { \% drug } \\
\text { dissolved }\end{array}$ & $\begin{array}{c}\text { 30 drug } \\
\text { minute }\end{array}$ & $\begin{array}{c}\text { \% drug } \\
\text { dissolved }\end{array}$ & $\begin{array}{c}\text { \% drug } \\
\text { minute } \\
\text { dissolved }\end{array}$ \\
\hline 1 & 0.097 & 33.10 & 0.189 & 64.50 & 0.258 & 88.05 & 0.299 & 102.04 & 0.301 & 102.73 \\
\hline 2 & 0.098 & 33.44 & 0.197 & 67.23 & 0.201 & 68.60 & 0.275 & 93.85 & 0.278 & 94.88 \\
\hline 3 & 0.115 & 39.24 & 0.177 & 60.40 & 0.238 & 81.22 & 0.302 & 103.07 & 0.306 & 104.43 \\
\hline 4 & 0.109 & 37.20 & 0.199 & 67.91 & 0.255 & 87.03 & 0.287 & 97.95 & 0.291 & 99.31 \\
\hline 5 & 0.112 & 38.22 & 0.184 & 62.79 & 0.221 & 75.42 & 0.296 & 101.02 & 0.298 & 101.70 \\
\hline 6 & 0.118 & 40.27 & 0.173 & 59.04 & 0.234 & 79.86 & 0.273 & 93.17 & 0.278 & 94.88 \\
\hline
\end{tabular}

\section{Robustness}

The robustness was tested by changing several parameters of the dissolution method subsequently, equipment, analyst and laboratory. The dissolution test was performed on six Noscapine tablets for 45 min using $900 \mathrm{~mL}$ of $0.1 \mathrm{~N} \mathrm{HCl}$ as medium in Apparatus 2 at 100 RPM in different laboratories, with two different analysts and with two different analytical instruments in the same laboratory. Aliquots of $10 \mathrm{~mL}$ were filtered and analyzed by the UV method. The dissolution data were compared with the initial data. [11-14] 


\section{RESULTS AND DISCUSSION}

Determination of Solubility: As Noscapine is not soluble in water and phosphate buffer pH6.8, distilled water and phosphate buffer pH6.8 were not selected for media has solubility in $0.1 \mathrm{~N} \mathrm{HCI} \mathrm{so,} \mathrm{it} \mathrm{was} \mathrm{selected} \mathrm{for} \mathrm{media}$

Quality control test results of 15-mg Noscapine tablets containing Noscapine complied with IP specifications. (Results not reported.)

\section{Mechanical Calibration of Dissolution Apparatus}

Dissolution apparatus was calibrated as per guidelines. [14, 15]

\section{Optimization of Dissolution method}

$0.1 \mathrm{~N}$ hydrochloric acid is suitable dissolution media. The results of the dissolution study are depicted in Figures.

Dissolution of drug from a dosage form involves two consecutive steps, liberation of the drug from the formulation matrix which is disintegration followed by dissolution of

The drug which is solubilization of the drug particles in the dissolution medium.

The optimum dissolution conditions for the assessment of release were $900 \mathrm{~mL}$ of $0.1 \mathrm{~N} \mathrm{HCl}$ at $37^{\circ} \mathrm{C}$ as the dissolution medium, paddle apparatus at a stirring speed of 100

RPM and 45 min as collection time.

\section{Specificity}

When the placebo tablets were subjected to the dissolution test and analyzed, the absorbance was equivalent to $1.71 \%$ of Noscapine tablet concentration. According to ICH guidelines, the dissolution method is specific if the interference is not more than $2 \%$. The dissolution method was specific.

\section{Linearity}

For Assessing linearity, a standard curve for Noscapine was constructed by plotting average absorbance versus concentration. The linearity was evaluated by linear regression analysis. The curves show good linearity in the range of $1-9 \mu \mathrm{g} / \mathrm{mL}$. The line equation was $\mathrm{y}=0.141 \mathrm{x}+$ 0.043 with a slope of and $\mathrm{R}^{2}=0.999$. The RSD for each point was less than $2 \%$. These data indicate that the method is linear for Noscapine within the specification limits.

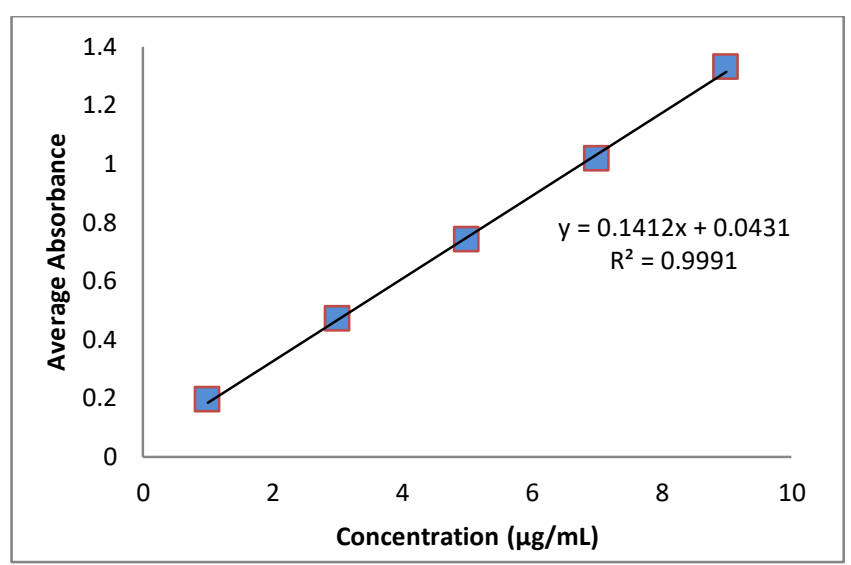

\begin{tabular}{|c|c|c|c|}
\hline $\begin{array}{c}\text { Sr. } \\
\text { No. }\end{array}$ & $\begin{array}{c}\text { Concentration } \\
(\boldsymbol{\mu g} / \mathbf{m L})\end{array}$ & $\begin{array}{c}\text { Abs (mean } \mathbf{\text { SD}}) \\
(\mathbf{n}=\mathbf{5})\end{array}$ & \% RSD \\
\hline 1 & 1 & $0.192 \pm 0.0029$ & 1.54 \\
\hline 2 & 3 & $0.468 \pm 0.0029$ & 0.62 \\
\hline 3 & 5 & $0.738 \pm 0.0032$ & 0.44 \\
\hline 4 & 7 & $1.015 \pm 0.0130$ & 1.30 \\
\hline 5 & 9 & $1.330 \pm 0.0053$ & 0.40 \\
\hline
\end{tabular}

\section{Accuracy}

The accuracy expresses the agreement between the accepted value and the observed value. The recovery for a dissolution test must be in the range of $95-105 \%$, according to ICH guidelines. The percent recovery was from $96.407 \%$ to $100.24 \%$. The accuracy of the method is acceptable.

Table 3:

\begin{tabular}{|c|c|c|c|c|c|c|c|}
\hline $\begin{array}{c}\text { Tablet } \\
\text { amount }\end{array}$ & $\begin{array}{c}\text { Level of } \\
\text { addition (\%) }\end{array}$ & $\begin{array}{c}\text { Amount } \\
\text { added (mg) }\end{array}$ & Absorbance & $\begin{array}{c}\text { Total } \\
\text { amount }\end{array}$ & $\begin{array}{c}\text { Amount } \\
\text { recovered (mg) }\end{array}$ & $\begin{array}{c}\text { \% } \\
\text { Recovery }\end{array}$ & $\begin{array}{c}\text { Average \%o } \\
\text { recovery }\end{array}$ \\
\hline- & 0 & - & 0.254 & 1.49 & - & - & - \\
\hline- & 0 & - & 0.257 & 1.51 & - & - & - \\
\hline- & 0 & - & 0.255 & 1.50 & - & - & - \\
\hline $15 \mathrm{mg}$ & & 12 & 0.423 & 2.69 & 11.89 & 99.09 & 99.48779 \\
\hline $15 \mathrm{mg}$ & 80 & 12 & 0.427 & 2.72 & 12.17 & 101.45 \\
\hline $15 \mathrm{mg}$ & & 12 & 0.421 & 2.68 & 11.75 & 97.91 & \\
\hline $15 \mathrm{mg}$ & & 15 & 0.467 & 3.01 & 15.01 & 100.07 & 98.50276 \\
\hline $15 \mathrm{mg}$ & 100 & 15 & 0.463 & 2.97 & 14.73 & 98.18 & \\
\hline $15 \mathrm{mg}$ & & 15 & 0.461 & 2.96 & 14.58 & 97.24 & \\
\hline $15 \mathrm{mg}$ & & 18 & 0.507 & 3.29 & 17.85 & 99.15 & 98.37142 \\
\hline $15 \mathrm{mg}$ & 120 & 18 & 0.506 & 3.28 & 17.78 & 98.76 \\
\hline $15 \mathrm{mg}$ & & 18 & 0.502 & 3.25 & 17.49 & 97.18 & \\
\hline
\end{tabular}




\section{Precision:}

6.10.4(a) Repeatability

Table 4: Repeatability data for dissolution method

\begin{tabular}{|c|c|c|}
\hline Sr. No. & Absorbance & \% Drug dissolved \\
\hline 1 & 0.287 & 97.95 \\
\hline 2 & 0.288 & 98.29 \\
\hline 3 & 0.289 & 98.63 \\
\hline 4 & 0.287 & 97.95 \\
\hline 5 & 0.287 & 97.95 \\
\hline 6 & 0.288 & 98.29 \\
\hline & Average & 98.17 \\
\hline & SD & 0.278668 \\
\hline & \% RSD & 0.283834 \\
\hline
\end{tabular}

6.10.4. (b) intermediate precision

Table 5: Intraday precision data for dissolution method

\begin{tabular}{|c|c|c|c|}
\hline Sample No. & $\mathbf{T}_{1}$ & $\mathbf{T}_{2}$ & $\mathbf{T}_{3}$ \\
\hline \% drug dissolved (mean \pm SD) & $98.46 \pm 1.67$ & $98.00 \pm 1.68$ & $97.49 \pm 1.59$ \\
\hline \%RSD & 1.69 & 1.71 & 1.63 \\
\hline
\end{tabular}

Table 6: Interday precision data for dissolution method

\begin{tabular}{|c|c|c|c|}
\hline Sample No. & Day i & Day ii & Day iii \\
\hline \% drug dissolved (mean \pm SD) & $98.63 \pm 1.93$ & $97.66 \pm 1.82$ & $97.32 \pm 1.81$ \\
\hline \%RSD & 1.95 & 1.86 & 1.86 \\
\hline
\end{tabular}

The percent RSD did not exceed 5\% for the repeatability and intermediate (Interday and intraday) precision, demonstrating suitable precision.

Robustness:

Table 7: Robustness data (Change in analyst)

\begin{tabular}{|c|c|c|}
\hline Sr. No. & Analyst 1 & Analyst 2 \\
\hline \% drug dissolved (mean $\mathbf{\text { SD) }}$ & $98.52 \pm 1.74$ & $98.40 \pm 1.73$ \\
\hline \% RSD & 1.77 & 1.763 \\
\hline
\end{tabular}

Table 8: Robustness data (Change in equipment)

\begin{tabular}{|c|c|c|}
\hline Sr. No. & Equipment 1 & Equipment 2 \\
\hline \% drug dissolved (mean $\mathbf{\text { SD}}$ ) & $98.52 \pm 1.74$ & $98.23 \pm 1.78$ \\
\hline \% RSD & 1.77 & 1.81 \\
\hline
\end{tabular}

Table 9: Robustness data (Change in laboratory)

\begin{tabular}{|c|c|c|}
\hline Sr. No. & \% Recovery & \% Recovery \\
\hline \% drug dissolved (mean $\mathbf{\text { SD}}$ ) & $98.52 \pm 1.74$ & $98.23 \pm 1.78$ \\
\hline \% RSD & 1.77 & 1.81 \\
\hline
\end{tabular}


Table 10: Robustness data (Change in rotation speed, changing normality and volume of dissolution medium)

\begin{tabular}{|c|c|c|c|}
\hline Factor & Change level(n=3) & Average \% drug dissolved $\mathbf{\text { SD }}$ & \% RSD \\
\hline \multirow{4}{*}{ Rotation speed } & 98 & $99.31 \pm 2.04$ & 2.06 \\
\cline { 2 - 4 } & 100 & $100.11 \pm 1.38$ & 1.37 \\
\cline { 2 - 4 } & 102 & $100.57 \pm 1.19$ & 2.59 \\
\hline \multirow{3}{*}{$\begin{array}{c}\text { Normality of } \\
\text { dissolution medium }\end{array}$} & $0.09 \mathrm{~N}$ & $98.75 \pm 2.56$ & 1.38 \\
\cline { 2 - 4 } & $0.1 \mathrm{~N}$ & $99.43 \pm 1.38$ & 2.26 \\
\cline { 2 - 4 } & $0.11 \mathrm{~N}$ & $100.11 \pm 2.27$ & 0.51 \\
\hline \multirow{2}{*}{$\begin{array}{c}\text { Volume of } \\
\text { dissolution medium }\end{array}$} & $890 \mathrm{~mL}$ & $102.16 \pm 0.52$ & 0.86 \\
\cline { 2 - 4 } & $900 \mathrm{~mL}$ & $99.43 \pm 0.86$ & 0.52 \\
\cline { 2 - 4 } & $910 \mathrm{~mL}$ & $97.84 \pm 0.52$ & \\
\hline
\end{tabular}

The robustness of the method was demonstrated by changing the instrument, the analyst and the laboratory (interlaboratory study). The percent RSD values were within the specified limit of $5 \%$ indicating the robustness of dissolution method

\section{CONCLUSION}

The dissolution method was developed and validated for Noscapine tablets is satisfactory. The most discriminating conditions for dissolution testing of Noscapine tablets $[0.1 \mathrm{~N}$ $\mathrm{HCl}$ as a dissolution medium paddle apparatus, stirring speed of $100 \mathrm{rpm}$, and collection time of $45 \mathrm{~min}$ ) appear to be the best conditions. Validation shows that the dissolution test is appropriate for quantification of Noscapine in tablet pharmaceutical form for in vitro studies, presenting linearity and range, specificity, precision (intermediate and repeatability), accuracy, and robustness. The method is adequate for use in quality control testing of noscapine tablets

ACKNOWLEDGMENTS: The authors are thankful Sigma institute Of Pharmacy, for providing research facility and especially to Mrs. Puja vyas and Dr. Jigar vyas for giving helpful suggestions throughout.

\section{REFERENCES}

(1) Breier AR.; Paim CS.; Steppe M.; Schapoval EES. Development and validation of dissolution tests for fexofenadine hydrochloride capsules and coated tablets. J. Pharm. Pharm. Sci. 2005; 8(2):289-298.

(2) British Pharmacopoeia 2011. British Pharmacopoeia Commission, 2011; (1):1573-1575.

(3) European Pharmacopoeia VII. European Directorate for Quality of medicines and Health care, 2011; (2):2529-2530.
(4) Indian Pharmacopoeia, Pharmacopoeia commissionGhaziabad, Govt of India. Ministry of Health Family Welfare, 2010; (3): 1798-1800

(5) International conference on harmonization of technical requirements for registration of pharmaceutical for human use, validation of Analytical procedure: Text and Methodology ICH Q2 (R1), 2005.

(6) Japanese pharmacopoeia. Ministry of health, labour and welfare, 2009; 936.

(7) Karuppiah SP," Analytical method development for dissolution release of finished solid oral dosage forms" Int. J. Cur. Pharm. Res., 2012; (4): 48-53.

(8) Kulkarni AP, Shahnawaz M, Zaheer Z, Dehghan MH." Development and Validation of a Dissolution Method for Pioglitazone Tablets" dissolution technologies, 2012, 36-45

(9) Noscapine September
http://www.drugs.com/international/noscapine.html 2015 ,

(10) Sperandeo NR; Kassuha DE. Development and Validation of a Dissolution Test for $6 \mathrm{mg}$ Deflazacort Tablets. Sci. Pharm. 2009; (77):679-693.

(11) Swartz M. and Emanuele M.," Developing and Validating Dissolution Procedures for Improved Product Quality" synomicspharma, 2012; 1-12.

(12) Validation of Analytical procedures: Text and methodology, Geneva, 2005.

(13) Shah VP, Lesko LJ, Fan J, Fleischer N, Handerson J, Malinowski H, Makary M, Ouderkirk L, Roy S, Sathe P, Singh GJP, Tillman L, Tsong Y, Williams RL, "FDA guidance for industry: dissolution testing of immediate release solid oral dosage forms", Dissolution Technol. 1997; (4):15-29

(14) The United States Pharmacopeia and National Formulary USP 27-NF 24; the United States Pharmacopeial Convention, Inc.: Rockville, MD, 2007

(15) United States Pharmacopoeia 35-National Formulary-30, the United States Pharmacopeial Convention Rockville, 2012; 3120 . 